\title{
Carbohydrate Levels and Control of Blackjack Oak and Winged Elm Treated with Tebuthiuron and 2,4,5-T
}

\author{
J.P. SHROYER, J.F. STRITZKE, AND L.I. CROY
}

\begin{abstract}
The effects of tebuthiuron $\mathrm{N}$-[5(1,1-dimethylethyl)-1,3,4-triadiazol-2-yl]-N,N' dimethylurea) and 2,4,5-T[(2,4,5-trichlorophenoxy) acetic acid] on total nonstructural carbohydrates (TNC) in the roots of blackjack oak (Quercus marilandica Muench.) and winged elm (Ulmus alata Michx) were evaluated. Tebuthiuron was applied to the soil in February 1976 at $2.24 \mathrm{~kg} / \mathrm{ha}$ and $2,4,5-\mathrm{T}$ was foliar applied at $2.24 \mathrm{~kg} / \mathrm{ha}$ in May 1976 . Tree kill 1 year after treatment with tebuthiuron was $100 \%$ for both woody species. No tree kill resulted from treatment with 2,4,5-T, and canopy reduction after 1 year was 50 and $70 \%$ for winged elm and blackjack oak, respectively. The TNC content of both winged elm and blackjack oak roots was significantly reduced following application of 2,4,5-T and tebuthiuron. The TNC content of roots from trees growing in tebuthiuron-treated areas did not significantly increase after treatment (TNC contents of 6 and 7\%, respectively for blackjack oak and winged elm on October 13). There was some increase in TNC content of roots from trees sprayed with 2,4,5-T, and by October the TNC content in blackjack oak and winged elm roots was 10 and $19 \%$, respectively. This compared to TNC contents of 36 and $32 \%$, respectively for untreated blackjack oak and winged elm.
\end{abstract}

Phenoxy herbicides, such as 2,4,5-T, have been the herbicides most commonly used for brush control. Elwell (1964) and Darrow and McCully (1955) indicated that two aerial applications of 2,4,5-T totaling 3.36 to $4.48 \mathrm{~kg} / \mathrm{ha}$, with not more than 2 years between treatments, were required to effectively control blackjack oak (Quercus marilandica Muench.) and post cak (Quercus stellata Wangenh.). Elwell (1968) concluded that foliar applications of 2,4,5-T did not effectively control winged elm (Ulmus alata Michx.). Stritzke (1975) found that the addition of ammonium thiocyanate to $2,4,5-\mathrm{T}$ consistently increased control of winged elm compared to $2,4,5-\mathrm{T}$ alone. Canopy reduction after treatments with $2,4,5-\mathrm{T}$ was often short-lived since resprouting soon occurred. This resprouting has been attributed to carbohydrate reserves in the roots of the treated trees.

Tebuthiuron has shown promise for control of certain brush species. Soil treatments of $2.24 \mathrm{~kg} / \mathrm{ha}$ on mixed brush have given excellent control of elms (Ulmus spp.) and oaks (Quercus spp.), (Stritzke 1976, Nickels and Stritzke 1977). Baur and Bovey (1975) observed good control of yaupon (Ilex vomitoria Ait.), post oak, and blackjack oak with soil applications of tebuthiuron using 2.24 to $4.48 \mathrm{~kg} / \mathrm{ha}$. There is usually only the initial defoliation of trees treated with $2,4,5-\mathrm{T}$; whereas, there

\footnotetext{
Authors are, graduate research assistant and associate professors, Department of Agronomy, Oklahoma State University, Stillwater, Oklahoma 74074. Mr. Shroyer is currently extension agronomist, lowa State University.

Journal Article 3411 of the Agricultural Experiment Station, Stillwater, Oklahoma.

Manuscript received January 3, 1978.
}

are several repeated defoliations caused by tebuthiuron during the first season following application, and some additional defoliations have been noted into the second and third years after treatment.

The objectives of this study were to evaluate the control as well as defoliation and resprouting of blackjack oak and winged elm treated with 2,4,5-T and tebuthiuron, and to determine the total nonstructural carbohydrate (TNC) levels in roots of both species.

\section{Materials and Methods}

Individual winged elm and blackjack oak trees located near Stillwater, Oklahoma, were utilized in the study. Winged elm trees were planted on a 3- $\mathrm{m}^{2}$ grid in 1971. The soil type was a Port silt loam (fine silty, mixed, Thermic Cumulic Haplustolls). The blackjack oak trees were resprouts growing on a Bates fine sandy loam site (fine loamy, siliceous, Thermic Typic Argiudolls) that had been bulldozed in 1964.

On February 12, 1976, 125 winged elm trees were each treated with 7.5 grams of tebuthiuron ( $10 \%$ pellets) applied on a $1.8 \mathrm{~m}^{2}$ area around each tree (equivalent to $2.24 \mathrm{~kg} / \mathrm{ha}$ ). In the blackjack oak area five plots $\left(15.2 \mathrm{~m}^{2}\right)$ were treated at the same rate with tebuthiuron. On May 28,1976 , three blackjack oak plots $\left(15.2 \mathrm{~m}^{2}\right)$ and 60 winged elm trees were foliar treated with a solution of 2,4,5-T, butoxyethanol ester. The solutions were as follows: blackjack oak $-95 \mathrm{ml}$ of 2,4,5-T (480 $\mathrm{g} / 1)$ plus $95 \mathrm{ml}$ of diesel in 18.9 liters of water foliar applied with a hand sprayer until the solution dripped from the leaves; winged elm-a mixture of $63 \mathrm{ml}$ of $2,4,5-\mathrm{T}(480 \mathrm{~g} / \mathrm{l})$ in 3.8 liters of water sprayed for 9 seconds with a hand sprayer (both treatments equivalent to $2.24 \mathrm{~kg} / \mathrm{ha}$ of $2,4,5-\mathrm{T}$ ).

Sampling of roots of both species for untreated trees began on February 12,1976 . Trees treated with tebuthiuron were first sampled April 26, 1976, and sampling for trees treated with 2,4,5-T began on June 8, 1976. Sampling was done twice monthly until September 15, 1976, once each in October (1976), April (1977), and June (1977). Root samples were collected from five trees within each treatment on each sampling date, except that on the September and October dates only two winged elm trees were sampled from the tebuthiuron areas since three of the trees were dead.

Roots that were sampled, ranging from 0.5 to $3.0 \mathrm{~cm}$ in diameter, were placed in an oven $\left(65^{\circ} \mathrm{C}\right)$ and dried for 48 hours. After drying, the bark was removed by scraping with a pocket knife and the roots were ground in a Wiley mill to pass through a $2-\mathrm{mm}$ screen. After the root samples were ground, $0.5 \mathrm{gm}$ of the root sample was placed in a $250-\mathrm{ml}$ beaker with $50 \mathrm{ml}$ of $0.2 \mathrm{~N} \mathrm{HCl}$ and allowed to boil slowly for $\mathrm{l}$ hour. The root solution was then filtered into a $100-\mathrm{ml}$ volumetric flask. The beaker and filtrate were washed with $50 \mathrm{ml}$ deionized water, and the solution was then brought to $100 \mathrm{ml}$ volume. Then $0.1 \mathrm{ml}$ of this sample was placed into a $20-\mathrm{ml}$ test tube with $0.9 \mathrm{ml}$ of deionized water. The Anthrone reagent, as described by Yemm and Willis (1954), was used to determine the TNC content. The Anthrone reagent $(5.0 \mathrm{ml})$ was then added to the root extract and agitated. The samples 
were then placed in a hot water bath for 15 minutes, followed by 20 minutes in a cold water bath. Optical density of the samples was determined with a spectrophotometer (B and L Spectronic 20) at 620 $\mathrm{nm}$. Standards containing $0,4080,120,200 \mu \mathrm{g}$ glucose/ml water served for comparison with the unknown TNC content of the root samples.

The vegetative stage and percentage defoliation of each tree was visually estimated on each sampling date. Also, canopy and tree mortality was determined on May 25, 1977. Trees were considered dead if there were no resprouts and cambium at ground level was dead.

The design was a randomized complete block and difference were separated by Duncan multiple range test.

\section{Results}

Tebuthiruon injury to winged elm was detected earlier than injury to black jack oak, and by July 8 the winged elm trees were completely defoliated (Table 1). Defoliation of blackjack oak treated with tebuthiuron increased with time and by September 15 they were completely defoliated. Defoliation was less with $2,4,5-\mathrm{T}$, and by October 13 the average defoliation was $80 \%$ for both blackjack oak and winged elm. Leaves on untreated trees were still green at this time. At the May 25, 1977, evaluation, all winged elm and blackjack oak trees treated with tebuthiuron were dead (no leaves on the original stems, no sign of resprouts, and no green cambium at ground level). At the May 1977 evaluation, none of the trees sprayed with 2,4,5-T were dead, although canopy kill averaged 50 and $70 \%$, respectively, for winged elm and blackjack oak with no basal sprouting.

Table 1. Defoliation (\%) of blackjack oak and winged elm on various sampling dates after treatment with tebuthiuron and $2,4,5-T^{1}$.

\begin{tabular}{|c|c|c|c|c|}
\hline \multirow[b]{3}{*}{ Sampling date } & \multicolumn{4}{|c|}{ Defoliation } \\
\hline & \multicolumn{2}{|c|}{ Blackjack oak } & \multicolumn{2}{|c|}{ Winged elm } \\
\hline & Tebuthiuron & $2,4,5-\mathrm{T}$ & Tebuthiuron & $2,4,5-\mathrm{T}$ \\
\hline \multicolumn{5}{|l|}{1976} \\
\hline $4 / 26$ & 10 & -2 & 30 & - \\
\hline $5 / 13$ & 25 & - & 45 & - \\
\hline $5 / 25$ & 30 & - & 90 & 一 \\
\hline $6 / 8$ & 50 & 20 & 90 & 25 \\
\hline $6 / 23$ & 45 & 70 & 90 & 60 \\
\hline $7 / 8$ & 90 & 50 & 100 & 60 \\
\hline $7 / 21$ & 90 & 70 & 100 & 50 \\
\hline $8 / 4$ & 90 & 65 & 100 & 50 \\
\hline $8 / 18$ & 90 & 70 & 100 & 65 \\
\hline $9 / 1$ & 90 & 70 & $90^{3}$ & 50 \\
\hline $9 / 15$ & 100 & 90 & $90^{3}$ & 70 \\
\hline $10 / 13$ & 100 & 80 & $90^{3}$ & 80 \\
\hline \multicolumn{5}{|l|}{1977} \\
\hline $5 / 25$ & 100 & 70 & 100 & 50 \\
\hline
\end{tabular}

Tebuthiuron applied Febriary 12. 1976, and 2,4,5-T applied May. 281976. $-=$ No data taken.

Contains only two observations.

'Defoliation taken in May. 1977. is considered to be canopy kill since data was taken 1 ycar after treatment.

On the first sampling date (February 12, 1976) the roots of untreated winged elm contained $23 \%$ TNC (Fig. 1). There was a decline in TNC levels with leaf initiation in early spring and TNC was less than $14 \%$ by April. After the leaves were full size (4 to $6 \mathrm{~cm}$ long) TNC began to increase, and by the October sampling the roots contained $32 \%$ TNC. The TNC content in the roots of untreated blackjack oak in February was essentially the same as that for the untreated winged elm (Fig. 2). The major difference was that the rate of decline of TNC in the roots of blackjack oak was delayed, resulting in a greater TNC content in the blackjack oak roots in late March and early April. By May

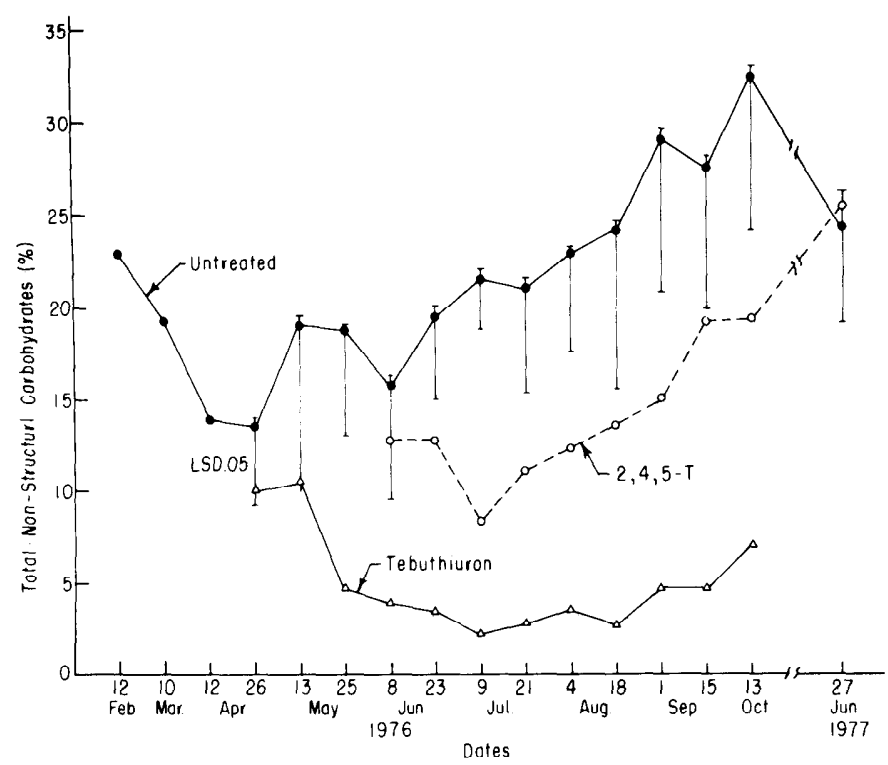

Fig. 1. Nonstructural carbohydrate levels in roots of winged elm at various dates and influence of tebuthiuron and 2,4,5-T on these concentrations. Trees were dormant at the February sampling, budding at the March sampling, leaves expanding during April, and some leaves full size by May.

13 the leaves were fully developed and the TNC began to accumulate. This type of TNC pattern exhibited by the untreated trees was in agreement with previous reports by Kramer and Kozlowski (1960).

On April 26 winged elm treated with tebuthiuron had a TNC content in the roots of $10 \%$ compared to $13 \%$ in the roots from untreated trees. The TNC content in roots of the treated trees continued to decline and by August 18 it was only 3\%. The cambium at ground level of some of the trees was dead by the September sampling. TNC content in roots of live trees averaged $4 \%$ on September 1, 5\% on September 15, and $7 \%$ on October 13. Defoliation of these trees averaged $90 \%$ on all three sampling dates. None of the winged elm trees were alive by the

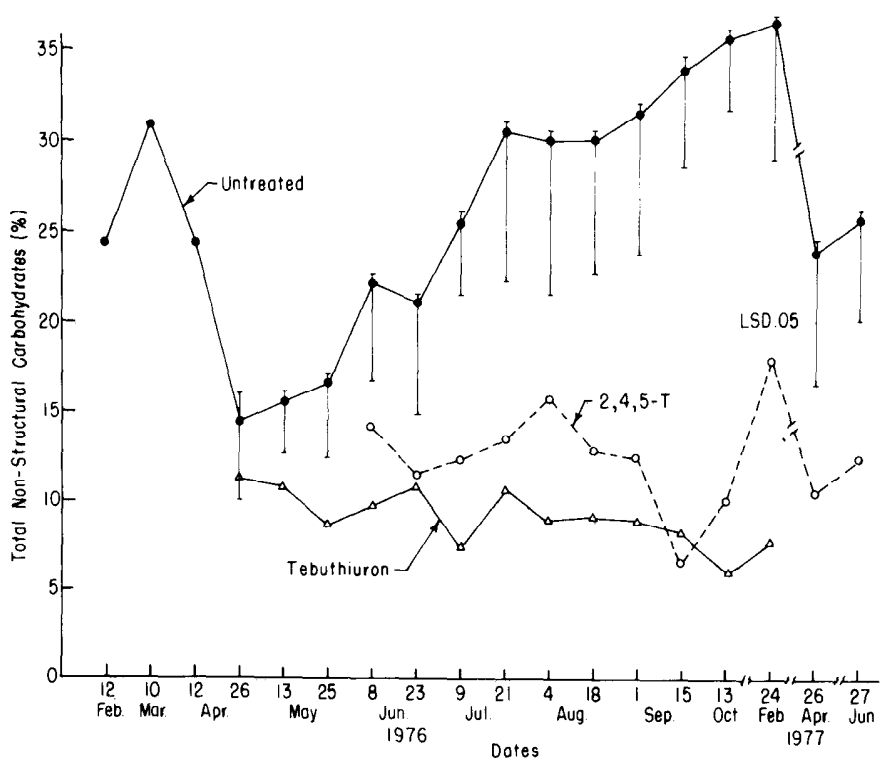

Fig. 2. Nonstructural carbohydrate levels in roots of blackjack oak at various dates and influence of tebuthiuron and 2,4,5-T on these concentrations. Trees were dormant at the February samplings, budding at the March samplings, expanding during April and May, and full size by June samplings. 
following spring (May 1977); therefore sampling was discontinued.

The TNC content in roots of winged elm sprayed with $2,4,5-\mathrm{T}$ was also influenced but the effect was not as dramatic and long lasting as with the tebuthiuron treatments (Fig. 1). The lowest TNC content (18\%) occurred on July 8 . After July 8 , there was an increase in TNC in roots of winged elm treated with $2,5,5-\mathrm{T}$ which essentially paralleled the increase in untreated trees. This increase in TNC evidently resulted from activity of leaves remaining on the trees, since $30 \%$ or more of the canopy remained alive through October. By the following year (June $27,1977)$, there was no difference in the TNC content between untreated trees and those treated with 2,4,5-T. Boo and Pettit (1975) reported the same type of recovery of TNC in roots of sand shinnery oak (Quercus harvardii Rydb.) after mechanical shredding.

When blackjack oak trees treated with tebuthiuron were first sampled (April 26), the roots contained $11 \%$ TNC (Fig. 2). This was only $3 \%$ less than the untreated trees on the same date. However, treated trees had lower TNC than untreated trees on May 13. The percent TNC in roots of tebuthiuron-treated trees was between 7 and $11 \%$ for most of the summer, reaching a low of $6 \%$ by the October 13,1976 , sampling.

The TNC content of roots of blackjack oak was also significantly reduced by the $2,4,5-\mathrm{T}$ treatment (Fig. 2 ). For most of the summer the reduction was similar to that of trees treated with tebuthiuron. The main difference was the increase of TNC content in roots of trees sprayed with 2,4,5-T. By February 1977 , the TNC content was $18 \%$ compared to $8 \%$ in roots from tebuthiuron-treated trees. No comparison of TNC levels in roots 1 year after treatment was made between the two herbicides since all trees treated with tebuthiuron were dead.
Tebuthiuron was more effective than $2,4,5-\mathrm{T}$ in reducing the TNC content in roots of both blackjack oak and winged elm in this study. There was also better defoliation of existing stems and tree kill with the tebuthiuron treatment. This was in agreement with results obtained by Scrifres and Mutz (1977) for white brush (Aloysia lycioides Cham.) and Berlandier wolfberry (Lycium berlandieri Dun.) where they observed no resprouting from trees 2 years aftcr being treated with tebuthiuron. This more effective tree kill and lack of resprouting when using tebuthiuron should significantly increase the longevity of effective brush control.

\section{Literature Cited}

Baur, J.R., and R.W. Bovey. 1975. Herbicidal effects of tebuthiuron and glyphosate. Agron. J. 67:547-553.

Boo, Robert M., and R.D. Pettit. 1975. Carbohydrate reserves in roots of sand shin oak in west Texas. J. Range Manage. 28:469-472.

Darrow, R.A., and W.G. McCully. 1955. Aerial application of herbicides for control of post and blackjack oaks. Proc. So. Weed Conf. 8:265-268.

Elwell, Harry M. 1964. Oak brush control improves grazing land. Agron. J. 56:411-415.

Elwell, Harry M. 1968. Winged elm control with picloram and 2,4,5-T with and without additives. Weed Sci. 16:131-133.

Kramer, P.J., and T.T. Kozlowski. 1960. Physiology of Trees. McGrawHill, New York 642 p.

Nickels, J.K., and J.F. Stritzke. 1977. Some potential uses of tebuthiuron and 3-cyclohexyl-6-(dimethylamino)-1-methyl-1,3,5,-triazine-2,4(1H,3H)-dione in pine management. Proc. So. Weed. Conf. 30:246.

Scifres, C.S., and J.L. Mutz. 1977. Brush control and range forage production following aerial application of tebuthiuron. Proc. So. Weed Conf. 23:131-136.

Stritzke, J.F. 1975. Chemical mixtures for control of winged elm. Weed Sci. 23:131-136.

Stritzke, J.F. 1976. Use of tebuthiuron for control of undesirable vegetation in pastures and range. Weed Sci Abstr. $38 \mathrm{p}$

Yemm, E.W., and A.J. Willis. 1954. The estimation of carbohydrates in plant extracts by anthrone. Biochem. J. 57:508-514.

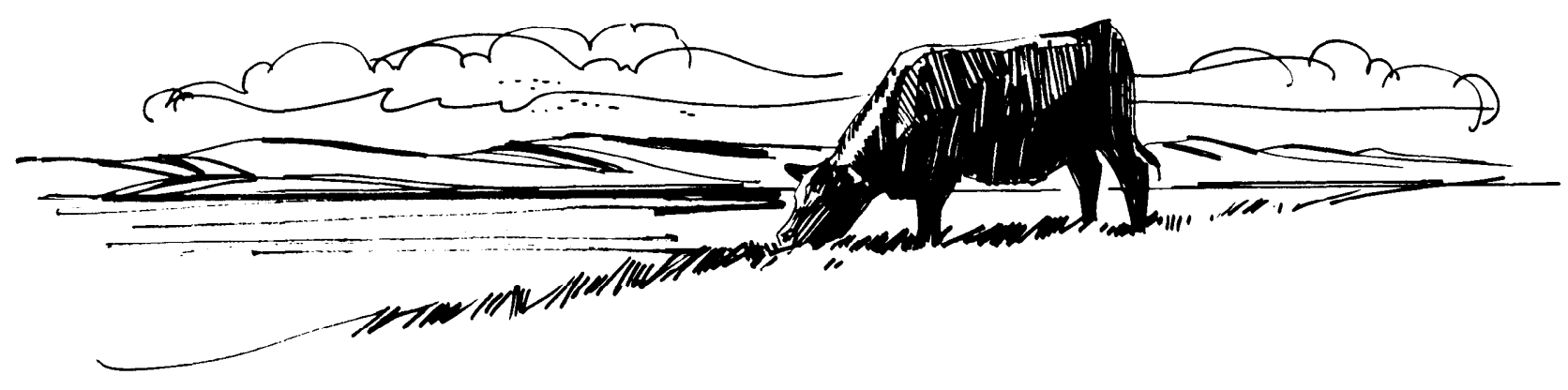

